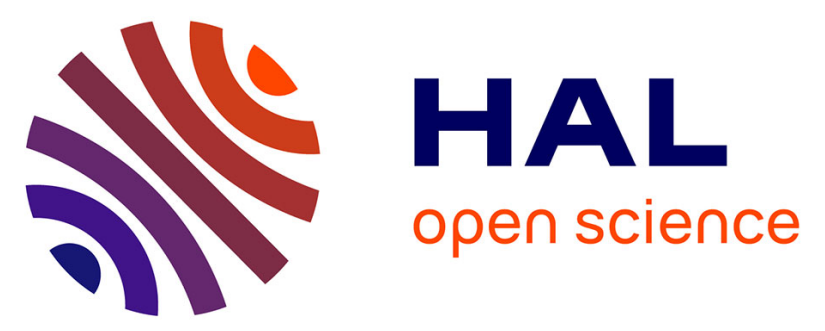

\title{
Sequence of administration and methylation of SOCS3 may govern response to Gemtuzumab ozogamicin in combination with conventional chemotherapy in patients with refractory or relapsed acute myelogenous leukemia (AML)
}

Iris Middeldorf, Oliver Galm, Rainhardt Osieka, Edgar Jost, James G Herman, Stefan Wilop

\section{- To cite this version:}

Iris Middeldorf, Oliver Galm, Rainhardt Osieka, Edgar Jost, James G Herman, et al.. Sequence of administration and methylation of SOCS3 may govern response to Gemtuzumab ozogamicin in combination with conventional chemotherapy in patients with refractory or relapsed acute myelogenous leukemia (AML). American Journal of Hematology, 2010, 85 (7), pp.477. 10.1002/ajh.21723 . hal00552324

\author{
HAL Id: hal-00552324 \\ https://hal.science/hal-00552324
}

Submitted on 6 Jan 2011

HAL is a multi-disciplinary open access archive for the deposit and dissemination of scientific research documents, whether they are published or not. The documents may come from teaching and research institutions in France or abroad, or from public or private research centers.
L'archive ouverte pluridisciplinaire HAL, est destinée au dépôt et à la diffusion de documents scientifiques de niveau recherche, publiés ou non, émanant des établissements d'enseignement et de recherche français ou étrangers, des laboratoires publics ou privés. 


\section{American Journal of Hematology}

WILEY

\section{Sequence of administration and methylation of SOCS3 may govern response to Gemtuzumab ozogamicin in combination with conventional chemotherapy in patients with refractory or relapsed acute myelogenous leukemia (AML)}

\begin{tabular}{|r|l|}
\hline Journal: & American Journal of Hematology \\
\hline Manuscript ID: & AJH-10-0115.R1 \\
\hline Wiley - Manuscript type: & Research Article \\
\hline Date Submitted by the \\
Author: & 23-Mar-2010 \\
\hline Complete List of Authors: & $\begin{array}{l}\text { Middeldorf, Iris; Universitaetsklinikum Aachen, Medizinische Klinik } \\
\text { IV } \\
\text { Galm, Oliver; Universitaetsklinikum Aachen, Medizinische Klinik IV } \\
\text { Osieka, Rainhardt; Universitaetsklinikum Aachen, Medizinische } \\
\text { Klinik IV } \\
\text { Jost, Edgar; Universitaetsklinikum Aachen, Medizinische Klinik IV } \\
\text { Herman, James; Johns Hopkins University, The Sidney Kimmel } \\
\text { Comprehensive Cancer Center } \\
\text { Wilop, Stefan; Universitaetsklinikum Aachen, Medizinische Klinik IV }\end{array}$ \\
\hline Keywords: & $\begin{array}{l}\text { AML- molecular diagnosis \& therapy, Gemtuzumab ozogamicin, } \\
\text { SOCS3, treatment schedule }\end{array}$ \\
\hline
\end{tabular}

\section{ScholarONE" \\ Manuscript Central}




\title{
Sequence of administration and methylation of SOCS3 may govern
} response to Gemtuzumab ozogamicin in combination with

\author{
conventional chemotherapy in patients with refractory or relapsed
} acute myelogenous leukemia (AML)

\author{
Iris Middeldorf, $\mathrm{MD}^{\mathbf{1}}$; Oliver Galm, $\mathrm{MD}^{\mathbf{1}}$; Rainhardt Osieka, Prof ${ }^{1}$; Edgar Jost, \\ $\mathrm{MD}^{\mathbf{1}}$; James G. Herman, Prof ${ }^{2}$; Stefan Wilop, MD $^{1}$ \\ ${ }^{1}$ Medizinische Klinik IV, Universitaetsklinikum Aachen, RWTH Aachen, Germany \\ ${ }^{2}$ The Sidney Kimmel Comprehensive Cancer Center at Johns Hopkins, Baltimore, MD, \\ USA
}

\section{Corresponding author:}

Stefan Wilop, M.D.

Medizinische Klinik IV

Universitaetsklinikum Aachen, RWTH Aachen

Pauwelsstrasse 30

52074 Aachen

Germany

Phone: +492418089806

Fax: +492418082449

E-Mail: swilop@ukaachen.de

Running title: SOCS3 and Gemtuzumab ozogamicin in AML

Keywords: acute myelogenous leukemia; Gemtuzumab ozogamicin; SOCS3; treatment schedule

abstract word count: 250; text word count: 2993; tables: 2, figures: 4 


\begin{abstract}
:
Introduction: In older patients suffering from AML, aggressive chemotherapy is accompanied with high treatment-related morbidity and mortality. Gemtuzumab ozogamicin (GO), a humanized monoclonal anti-CD33 antibody, represents a well tolerated treatment option, but optimal treatment schedules are still unknown. Additionally, Suppressor of cytokine signaling 3 (SOCS3) inhibits the CD33-induced block on cytokine-induced proliferation. Consequently, a variable response of AML cells to anti-CD33-targeted therapy may be caused by modulation of SOCS3 expression. Patients and Methods: 24 patients with refractory or relapsed CD33-positive AML received GO as a single agent before or after conventional chemotherapy. The methylation status of the SOCS3 $\mathrm{CpG}$ island was assessed by methylation-specific polymerase chain reaction. Results: Response (RR) and overall survival (OS) were significantly higher in 16 patients receiving chemotherapy before GO (RR 81\%, OS 14.8 months) compared to 3 patients who received GO single agent therapy (RR 33\%, OS 7.2 months) or 16 with GO before chemotherapy (RR 0\% OS 2.2 months, $p=0.01$ for RR and $\mathrm{p}<0.001$ for OS). Methylation of the SOCS3 CpG island was found in $8 / 24$ patients. There was a trend towards a higher RR and longer OS in patients with SOCS3 hypermethylation (RR $86 \%$, OS 25.1 months) compared to unmethylated SOCS3 (RR 56\%, OS 10.3 months, $\mathrm{p}=0.09)$. Conclusion: Administration of GO a few days after chemotherapy seems to provide better response and survival compared to administration of GO directly prior to chemotherapy. The potential role of SOCS3 hypermethylation as a biomarker should be further investigated in patients undergoing GO containing therapies.
\end{abstract}




\section{Introduction}

Acute myelogenous leukemia (AML) is the most frequent acute leukemia in adults with a median age at diagnosis of 68 years ${ }^{1-3}$. In younger patients, 5 -year survival varies between $15 \%$ and $70 \%$ depending in particular on chromosomal aberrations ${ }^{4}$. For patients older than 60 years, prognosis is poor, because advanced age is associated with adverse cytogenetics, preceding myelodysplastic syndrome (MDS) and elevated activity of multidrug resistance genes ${ }^{5}$. Additionally, owing to severe comorbidities, aggressive chemotherapy is often accompanied with high treatment-related morbidity and mortality 2.

Gemtuzumab ozogamicin (GO) is a humanized monoclonal murine Ig4 antibody which is linked to the potent antitumor antibiotic calicheamicin and targets the CD33 antigen ${ }^{6-}$ 11. After internalization, calicheamicin is cleaved from the antigen-antibody complex and induces DNA double-strand breaks and apoptosis by sequence specific binding to DNA ${ }^{6,9,11}$. CD33 is expressed on $90-99 \%$ of AML blasts, myeloid precursors cells, macrophages, monocytes and dendritic cells, but not on hematopoietic stem cells ${ }^{9,11}$. CD33 is member of the sialic acid-binding immunoglobulin-like lectin (Siglec) family of inhibitor receptors, and its activation induces apoptosis and inhibition of proliferation in AML cells. GO represents a treatment option for AML and was approved by the Food and Drug Administration (FDA) as a single agent for relapsed AML in patients older than 60 years who are not eligible to receive cytotoxic chemotherapy.

DNA methylation of cytosines within $\mathrm{CpG}$ dinucleotides and post-translational acetylation of histones are the most common epigenetic modifications with an impact on chromatin structure and transcriptional activity. Hypermethylation of $\mathrm{CpG}$ islands in the promoter region of genes is a well-characterized epigenetic modification associated with transcriptional silencing of cancer-related genes and plays a crucial role in 
carcinogenesis ${ }^{12}$. Suppressor of cytokine signaling 3 (SOCS3) was shown to inhibit the CD33-induced block on cytokine-induced proliferation by leading to its degradation because of forming complexes with CD33 ${ }^{13}$. Consequently, Ball et al. suggested that a variable response of AML cells to anti-CD33-antibodies could be caused by differential levels or modulation of SOCS3 expression ${ }^{14}$.

We here report our retrospective analysis of characteristics and outcome of 24 AML patients, treated with GO as a single agent or in combination with chemotherapy in our institution. Additionally, the methylation status of the promoter-associated $\mathrm{CpG}$ island of SOCS3 was analyzed, because we hypothesized that patients with epigenetic dysregulation of SOCS3 may have a better response to GO owing to a decreased degradation of CD33.

\section{Patients and methods}

\subsection{Patients}

Between December 2000 and March 2009, overall 156 patients have been treated for AML in our institution, including 81 patients with relapsed or refractory AML. At the individual physician's discretion, after consideration of CD33 expression, performance status (PS) and risk factors, 24 patients received a GO-containing therapy. If patients repeatedly received $\mathrm{GO}$, we here report on the first GO containing treatment cycle only. All patients had an Eastern Cooperative Oncology Group performance status $\leq 2$ and no severe hepatic (bilirubin $<2.0 \mathrm{mg} / \mathrm{dl}$; aspartate aminotransferase $<100 \mathrm{U} / \mathrm{l}$ ) or renal (creatinine $<2.0 \mathrm{mg} / \mathrm{dl}$ ) dysfunction before starting treatment. Flow cytometric analysis of myeloblasts revealed positivity for CD33 in all 24 patients. Cytogenetic analyses were performed during routine clinical assessment and risk groups were classified according to Grimwade et al. ${ }^{15}$. 


\subsection{Matched pair analysis}

To compare treatment related toxicity and OS in our patient cohort treated with a GO containing therapy, we performed a matched pair analysis with patients treated without GO. Patients were matched for cytogenetic risk group, stage of disease (refractory, $1^{\text {st }}$ relapse, $\geq 2$ nd relapse) and age. Table I shows the characteristics of the patient cohort and matched control group.

\subsection{Treatment schedules}

GO was administered either as a single agent ("GO") or prior to ("GO $\rightarrow$ chx") or after (“chx $\rightarrow$ GO") various regimens with conventional chemotherapy. Table I shows the patient characteristics of the three treatment groups as well as the matched controls, table II the protocols and doses applied.

\subsection{Response evaluation}

Response was assessed as proposed by Cheson et al. ${ }^{16}$. Patients with all CR criteria but persistent thrombocytopenia (below $100 \times 10^{9} / \mathrm{L}$ ) were considered to have a CRp. Patients with recovery of peripheral blood (PB) values but at least $50 \%$ decrease of bone marrow (BM) blasts to $5-25 \%$ were reported to have a partial remission (PR). If less than $5 \%$ blasts were found in the BM without adequate recovery of peripheral blood counts, patients morphologic leukemia-free state (LFS) was considered. Response was considered in patients achieving a CR, CRp or PR ${ }^{16}$.

The National Cancer Institute Common Toxicity Criteria version 3.0 (NCI-CTC 3.0) was used for toxicity assessment. 


\subsection{Methylation specific PCR (MSP)}

From all patients with AML, BM and/or PB is routinely collected for analysis of genetic and epigenetic changes. The protocol was approved by the University hospital ethics committee and patients gave informed consent in accordance with the Declaration of Helsinki.

Genomic DNA was isolated from patient samples using standard methods. Approximately $1 \mu \mathrm{g}$ of DNA was sodium bisulfite-modified and subjected to MSP as described previously ${ }^{17}$. MSP primers that specifically recognized the unmethylated SOCS3 sequence were 5'-GTT GGA GGG TTT TGG GTA TTT AAT GT-3' (sense) and 5'-TAA ATA ACC ATA ACA CAC AAA ACC AAC A-3' (antisense); primers specific for the methylated SOCS3 sequence were 5'-TGG AGG GTT TCG GGT ATT TAA CGC-3' (sense) and 5'-ATA ACC ATA ACG CAC GAA ACC AAC G-3' (antisense). Reactions were hot-started at $95^{\circ} \mathrm{C}$ for $5 \mathrm{~min}$ and held at $80^{\circ} \mathrm{C}$ before addition of $0.625 \mathrm{U}$ of Taq polymerase. Temperature conditions for thermocycling were as follows: 35 cycles of $95^{\circ} \mathrm{C}$ for $30 \mathrm{sec}, 58^{\circ} \mathrm{C}$ for $30 \mathrm{sec}$ and $72^{\circ} \mathrm{C}$ for $30 \mathrm{sec}$, followed by 1 cycle of $72^{\circ} \mathrm{C}$ for 5 min. Normal DNA from PB was treated in vitro with SssI methyltransferase in order to generate in vitro methylated DNA (IVD) that served as a universally positive control for methylated alleles ${ }^{18}$. PCR products were separated on $2.5 \%$ agarose gels and visualized by ethidium bromide staining.

\subsection{Statistical analysis}

Correlations between categorical variables were tested using the chi-square test or Fisher's exact test where appropriate. Overall survival (OS) was calculated from the first day of treatment until death or last follow-up. Relapse-free survival (RFS) was calculated from the day achieving LFS until death or last follow-up. OS and RFS were analyzed using the Kaplan-Meier method and compared using the log rank test. 
All statistical tests are two-sided with a level of significance at $\mathrm{p}<0.05$. Statistical analyses were performed using the SAS software package version 9.1.3 (SAS Institute Inc., Cary, NC, USA).

\section{Results}

\subsection{Response}

Response evaluation was limited to 23 patients, since one patient received allogeneic stem cell transplantation during myelosuppression following GO containing therapy. Responses (including CR, CRp and PR) to the GO containing therapy were observed in 14 out of 23 patients (61\%). Twelve patients achieved CR (52\%), one patient CRp (4\%) and one patient PR (4\%).

The response rate was significantly higher in patients receiving chemotherapy before GO (81\% response) as compared to patients who received GO single agent therapy (33\% response) or GO before chemotherapy ( $0 \%$ response, $\mathrm{p}=0.01$, chi-square test). Since no CR was achieved in the latter two groups, relapse-free survival could not be compared between these groups (table II). Noticeably, eight out of nine patients with primary refractory disease achieved a CR using a second chemotherapy followed by GO.

The median OS of all patients was 10.9 months with a RFS of 7.4 months among the 13 patients who achieved CR/CRp. Survival was significantly associated with different treatment schedules: Median survival was only 2.2 months for patients receiving GO followed by chemotherapy, whereas patients with single agent GO therapy survived 7.2 months. In patients who received chemotherapy followed by GO, the longest median survival of 14.8 months was observed $(\mathrm{p}<0.001, \log$ rank test, figure 1$)$. 
Compared to our matched control group, OS of all patients treated with GO was 10.9 months, whereas the median OS of the matched control group was only 3.4 months (figure 2). This difference, however, did not reach statistical significance $(\mathrm{p}=0.11, \log$ rank test).

\subsection{Methylation status of SOCS3}

We performed MSP analysis to assess the methylation status of SOCS3 in BM samples of our patient cohort treated with a GO containing therapy, because we hypothesized that response to GO may be modulated by epigenetic dysregulation of SOCS3. Hypermethylation of the SOCS3 CpG island was found in 8/24 patients (33\%, Figure 3). The response rate was slightly higher in patients with SOCS3 methylation (86\% response) compared to unmethylated SOCS3 (56\% response, $\mathrm{p}=0.17$, chi-square test). Consequently, overall survival was longer in methylated cases (25.1 vs. 10.3 months, hazard ratio $0.29,95 \%$ confidence interval 0.06 to 1.32 , figure 4 ). However, the difference did not reach statistical significance $(\mathrm{p}=0.09, \log$ rank test).

\subsection{Toxicity}

All patients treated with GO experienced severe myelosuppression (grade 4 thrombocytopenia and neutropenia). The median time until recovery of blood platelets exceeding $50 \times 10^{9} / \mathrm{L}$ in patients with CR was 27 days (range 19-35 days). Recovery of ANC above $0.5 \times 10^{9} / \mathrm{L}$ was also observed on day 27 (range 11-59) in these patients. Neutropenic fever emerged in 21 of all patients $(88 \%)$, and one patient developed invasive aspergillosis after GO single agent therapy. However, sepsis with detection of pathogens in blood cultures seemed to be more frequent in the "GO"-group (67\%) and "GO $\rightarrow$ chx"-group (60\%), compared to the "chx $\rightarrow$ GO"-group (19\%). Additionally, grade $3 / 4$ elevation of bilirubin occurred in one patient (4\%), and in six patients $(25 \%)$, 
grade 3/4 elevation of liver enzymes (aspartate aminotransferase $=$ AST, alanine aminotransferase $=$ ALT) was observed. Statistical analysis revealed no significant differences in the frequency of side effects between the three treatment groups. Overall, we observed four early deaths (17\%) owing to infectious complications during severe myelosuppression.

In our matched control group, 23 out of 24 patients experienced grade 4 thrombocytopenia and all patients grade 4 neutropenia. Neutropenic fever emerged in 15 patients. Three patients died early due to infectious complications during severe myelosuppression. One additional patient died early owing to cerebral bleeding. We observed grade $3 / 4$ elevation of bilirubin in 3 patients without grade $3 / 4$ elevation of AST or ALT. Differences between the frequency of side effects in patients receiving GO and the matched control group were not statistically significant (all chi-square test).

\subsection{Subsequent treatment}

Following initial GO based chemotherapy, most patients later received additional treatment in the course of the disease: In three patients younger than 60 years, allogeneic stem cell transplantation (aSCT) was performed after achieving response to GO based treatment. One of these patients relapsed after 14 months, the remaining two patients are in continuous CR for 7 and 14 months, respectively. One additional patient, who did not respond to GO based therapy, underwent aSCT and subsequently died on day +68. Noticeably, although four patients underwent aSCT after a GO containing therapy, no veno-occlusive disease (VOD) was observed.

Five patients who achieved $\mathrm{CR}$ after GO based therapy received some GO based maintenance therapy. 


\section{Discussion}

AML is mainly a disease of advanced age, since more than half of the patients are older than $60{ }^{19}$ and one third older than 75 years ${ }^{2}$. In western countries, the incidence rate in patients older than 65 years is about 15 per $100.000 /$ year ${ }^{20,21}$. In young patients, successful treatment with aggressive chemotherapy is possible in many cases, but the outcome of older patients or in relapsed/refractory cases is extremely poor. Despite the possibility of achieving a CR in $40-60 \%$ in these cases using conventional chemotherapy ${ }^{2,19,22-24}$, the rate of DFS after 3 years is less than $10-20 \%^{19,22,24,25}$ with a median survival of only 5-12 months ${ }^{7,23}$. Owing to multiple comorbidities and reduced PS, aggressive chemotherapy continues to remain a challenge in older patients ${ }^{2}$. Additionally, time of hospitalization and therapy-related complications have to be considered. Consequently, targeted therapies have been developed to overcome the limitations of chemotherapy.

GO is a monoclonal antibody targeting the CD33 antigen linked to an antitumor antibiotic and has been approved for treatment of AML in the elderly. In the literature, many studies on GO-based therapies have been reported. Using GO as a single agent therapy in patients with refractory or relapsed AML, CR was achieved in 13 to $26 \%$, leading to a median OS of 4.9 to 12 months ${ }^{10,21,25-27}$. As a single agent, GO more likely induced a second CR than high dose araC especially in older patients with early relapse 28 .

In studies, in which GO was administered within a few days before chemotherapy, CR was achieved in 9.5 to $55 \%$ with a median OS of 2 to 8.2 months ${ }^{8,11,29-32}$. Chemotherapy followed by GO resulted in 10 to $70 \% \mathrm{CR}$ and a median OS of 2.3 to 11 months ${ }^{22,33-36}$. Doses of GO ranged from $3 \mathrm{mg} / \mathrm{m}^{2}$ to $9 \mathrm{mg} / \mathrm{m}^{2}{ }^{25,37}$. Thus, literature 
provides a wealth of options for GO-containing therapies, but optimal patient selection, dose, schedule and combination partners remain still unclear.

After approval of GO in the United States and as proposed by the early literature $10,29,30,37$, we started to use GO as a single agent or administered GO within a few days prior to conventional chemotherapy. Unfortunately, response and survival of our patient cohort until then was rather poor. Chevallier et al. ${ }^{34}$ reported in 2005 promising results using GO 4 days after chemotherapy. Consequently, we changed our schedule to chemotherapy followed by GO. In our patients treated with single agent GO or GO followed by chemotherapy, we achieved an overall response in only $33 \%$ and $0 \%$, respectively. Noticeably, no CR was observed. After changing our protocol to chemotherapy followed by GO, the response rate significantly increased to $81 \%$ (all $\mathrm{CR} / \mathrm{CRp}$ ). This marked increase translated into prolonged overall survival of 14.8 months, compared to 7.2 and 2.2 months in the "GO" or "GO $\rightarrow$ chx" group. Additionally, compared to a matched control group, a GO based treatment seemed to have a slight, but not statistical significant survival advantage in our patients comprising mainly refractory and relapsed AML.

Morris et al. showed an additive effect of GO and araC and etoposide in cell culture experiments. Thus, for combination of GO with chemotherapy, a better response compared to single agent GO should be expected ${ }^{38}$. However, the mechanism of the different response according to the sequence of GO and chemotherapy is not clear. Internalization and hydrolytic release of the toxic calicheamicin moiety causes DNA damage and cell cycle arrest ${ }^{39}$. Because most chemotherapeutic agents mainly target dividing cells, administration of GO before chemotherapy may lead to reduced efficacy of the following chemotherapy. The cytotoxic moiety of GO directly interacts with double-helical DNA in the minor groove and thereby causes site-specific doublestranded cleavage ${ }^{40}$. This effect seems to be independent of DNA replication, thus, 
prior administration of chemotherapy causing cell cycle arrest may not interfere with the effectiveness of GO. Additionally, a high CD33 antigen load in the peripheral blood simply consumes GO and thereby limits its penetration into the bone marrow. Prior chemotherapy may rapidly reduce CD33 antigen load and thus lead to a better efficacy of $\mathrm{GO}^{41}$.

Recently, Ball et al. suggested a possible interaction between CD33, the target of GO, and SOCS3, since intracellular SOCS3 binds to phosphorylated CD33 leading to proteosomal degradation of complexed SOCS3 and CD33 ${ }^{14}$. Consequently, we hypothesized that patients with epigenetic dysregulation of SOCS3 may have a better response owing to decreased degradation of CD33. In our patient cohort, we found promoter methylation of SOCS3 in 8 out of 24 cases (33\%). The response rate in these cases was $86 \%$, compared to $56 \%$ in cases without methylation of SOCS3. Overall survival was 25.1 months compared to 10.3 months, respectively. Statistical significance was not reached, possibly due to the relatively low patient number. However, the role of SOCS3 hypermethylation as a biomarker should further be investigated in a larger number of patients undergoing GO containing treatment.

Elevation of liver enzymes is a frequent side effect of GO, and grade 3/4 hepatic toxicity was reported in $30 \%$ after GO in combination with idarubicin and $\operatorname{araC}^{29}$. Quite in accordance with this, we observed $25 \%$ grade $3 / 4$ hepatic toxicity in our patient cohort. VOD, a severe complication with thrombosis of small liver veins, was reported with an incidence of $7-20 \%$ in studies using GO before chemotherapy ${ }^{8,29,32,37}$. However, in studies using GO after chemotherapy, incidence of VOD seems to be lower $22,33,36$. In our patient cohort, mainly including patients who received chemotherapy first followed by GO, no VOD was observed. Wadleigh et al. found the risk of VOD in patients who underwent myeloablative aSCT to be increased after prior GO exposure ${ }^{42}$. However, four of our patients received aSCT after GO without evidence of VOD. 
All of our patients treated with GO experienced severe myelosuppression with grade 4 neutropenia and thrombocytopenia. Both, the median time to recovery of ANC $>0.5 \mathrm{x}$ $10^{9} / \mathrm{L}$ and blood platelets $>50 \times 10^{9} / \mathrm{L}$ was 27 days and thus comparable to literature data ${ }^{10,19,26}$. During myelosuppression, in almost all patients $(88 \%)$ neutropenic fever emerged and four patients (17\%) subsequently died due to infectious complications. Treatment-related mortality was reported to be $5-13 \%$ in published studies using GO after chemotherapy ${ }^{22,33,36}$, whereas mortality in studies using GO before chemotherapy seemed to be higher (19-57\%) ${ }^{8,11,37,43}$.

Of note, multiple responses were observed in a single patient treated repeatedly with GO. One of our patients first received GO in $3^{\text {rd }}$ relapse, comprising GO after araC and thioguanine leading to a $\mathrm{CR}$, but this patient again relapsed after a few months. Subsequently, this patient was successfully treated with GO-containing regimens for seven times during the following 44 months.

Although the significance of our results is limited by the small number of patients, we propose that GO, given after chemotherapy, presents an efficient and safe therapeutic option for patients with refractory or relapsed AML, especially in advanced age. GO may even be administered, if a subsequent aSCT is planned. Administration of GO a few days after chemotherapy seems to provide better response and survival as well as fewer side effects compared to administration of GO directly prior to chemotherapy. Additionally, the methylation status of SOCS3 may modulate response to GO. In order to optimize patient selection and treatment schedules containing GO and to further elucidate the impact of SOCS3 hypermethylation on response and outcome, larger prospective studies are warranted. 


\section{Literature}

1. Deschler B, Lubbert M. Acute myeloid leukemia: epidemiology and etiology. Cancer 2006;107(9):2099-107.

2. Laubach J, Rao AV. Current and emerging strategies for the management of acute myeloid leukemia in the elderly. Oncologist 2008;13(10):1097-108.

3. Lowenberg B, Downing JR, Burnett A. Acute myeloid leukemia. N Engl J Med 1999;341(14):1051-62.

4. Wheatley K, Burnett AK, Goldstone AH, Gray RG, Hann IM, Harrison CJ, Rees JK, Stevens RF, Walker H. A simple, robust, validated and highly predictive index for the determination of risk-directed therapy in acute myeloid leukaemia derived from the MRC AML 10 trial. United Kingdom Medical Research Council's Adult and Childhood Leukaemia Working Parties. Br J Haematol. 1999;107(1):69-79.

5. Ferrara F, Palmieri S, Mele G. Prognostic factors and therapeutic options for relapsed or refractory acute myeloid leukemia. Haematologica 2004;89(8):9981008.

6. Bornhäuser M, Illmer T, Oelschlaegel U, Schetelig J, Ordemann R, Schaich M, Hänel M, Schuler U, Thiede C, Kiani A and others. Gemtuzumab ozogamicin as part of reduced-intensity conditioning for allogeneic hematopoietic cell transplantation in patients with relapsed acute myeloid leukemia. Clin Cancer Res 2008;14(17):5585-93.

7. Cascavilla N, D'Arena G, Greco MM, Melillo L, Merla E, Carella AM. Gemtuzumab ozogamicin as maintenance therapy after autologous stem cell transplantation in elderly patients with acute myeloid leukaemia. Br J Haematol 2008;142(5):852-3. 
8. Doyen J, Italiano A, Peyrade F, Bouyer C, Thyss A. Gemtuzumab ozogamicin plus cytarabine in elderly patients with relapsed or refractory acute myeloid leukaemia. Br J Haematol 2008;141(5):744-5.

9. Gleissner B, Schlenk R, Bornhäuser M, Berdel WE. Gemtuzumab ozogamicin (mylotarg) for the treatment of acute myeloid leukemia--ongoing trials. Onkologie 2007;30(12):657-62.

10. Sievers EL. Efficacy and safety of gemtuzumab ozogamicin in patients with CD33positive acute myeloid leukaemia in first relapse. Expert Opin Biol Ther 2001;1(5):893-901.

11. Specchia G, Pastore D, Carluccio P, Spinosa G, Giannoccaro M, Rizzi R, Mestice A, Liso V. Gemtuzumab ozogamicin with cytarabine and mitoxantrone as a thirdline treatment in a poor prognosis group of adult acute myeloid leukemia patients: a single-center experience. Ann Hematol 2007;86(6):425-8.

12. Esteller M. Epigenetics in cancer. N Engl J Med 2008;358(11):1148-59.

13. Orr SJ, Morgan NM, Elliot J, Burrows JF, Scott CJ, McVicar DM, Johnston JA. CD33 responses are blocked by SOCS3 through accelerated proteasomal-mediated turnover. Blood 2007;109(3):1061-1068.

14. Ball ED. Pairing SOCS with CD33. Blood 2007;109(3):1061.

15. Grimwade D, Walker H, Oliver F, Wheatley K, Harrison C, Harrison G, Rees J, Hann I, Stevens R, Burnett A and others. The importance of diagnostic cytogenetics on outcome in AML: analysis of 1,612 patients entered into the MRC AML 10 trial. The Medical Research Council Adult and Children's Leukaemia Working Parties. Blood 1998;92(7):2322-33.

16. Cheson BD, Bennett JM, Kopecky KJ, Büchner T, Willman CL, Estey EH, Schiffer CA, Doehner H, Tallman MS, Lister TA and others. Revised recommendations of the International Working Group for Diagnosis, Standardization of Response 
Criteria, Treatment Outcomes, and Reporting Standards for Therapeutic Trials in Acute Myeloid Leukemia. J Clin Oncol 2003;22(3):4642-9.

17. Herman JG, Graff JR, Myohanen S, Nelkin BD, Baylin SB. Methylation-specific PCR: a novel PCR assay for methylation status of CpG islands. Proc Natl Acad Sci U S A 1996;93(18):9821-6.

18. Galm O, Herman JG. Methylation-specific polymerase chain reaction. Methods Mol Med 2005;113:279-91.

19. Clavio M, Vignolo L, Albarello A, Varaldo R, Pierri I, Catania G, Balocco M, Michelis G, Miglino M, Manna A and others. Adding low-dose gemtuzumab ozogamicin to fludarabine, Ara-C and idarubicin (MY-FLAI) may improve diseasefree and overall survival in elderly patients with non-M3 acute myeloid leukaemia: results of a prospective, pilot, multi-centre trial and comparison with a historical cohort of patients. Br J Haematol 2007;138(2):186-95.

20. Zander AR, Bacher U, Finke J. Allogene Stammzelltransplantation bei der akuten myeloischen Leukämie. Deutsches Ärzteblatt 2008;105(39):663-669.

21. Larson RA, Sievers EL, Stadtmauer EA, Lowenberg B, Estey EH, Dombret H, Theobald M, Voliotis D, Bennett JM, Richie M and others. Final report of the efficacy and safety of gemtuzumab ozogamicin (Mylotarg) in patients with CD33positive acute myeloid leukemia in first recurrence. Cancer 2005;104(7):1442-52.

22. Fianchi L, Pagano L, Leoni F, Storti S, Voso MT, Valentini CG, Rutella S, Scardocci A, Caira M, Gianfaldoni G and others. Gemtuzumab ozogamicin, cytosine arabinoside, G-CSF combination (G-AraMy) in the treatment of elderly patients with poor-prognosis acute myeloid leukemia. Ann Oncol 2008;19(1):12834.

23. Roboz GZ. Treatment of acute myeloid leukemia in older patients. Expert Rev Anticancer Ther 2007;7(3):285-95. 
24. Tallman MS. New strategies for the treatment of acute myeloid leukemia including antibodies and other novel agents. Hematology Am Soc Hematol Educ Program 2005:143-50.

25. Amadori S, Suciu S, Willemze R, Mandelli F, Selleslag D, Stauder D, Ho A, Denzlinger C, Leone G, Fabris $\mathrm{P}$ and others. Sequential administration of gemtuzumab ozogamicin and conventional chemotherapy as first line therapy in elderly patients with acute myeloid leukemia: a phase II study (AML-15) of the EORTC and GIMEMA leukemia groups. Haematologica 2004;89(8):950-6.

26. Taksin AL, Legrand O, Raffoux E, de Revel T, Thomas X, Contentin N, Bouabdallah R, Pautas C, Turlure P, Reman O and others. High efficacy and safety profile of fractionated doses of Mylotarg as induction therapy in patients with relapsed acute myeloblastic leukemia: a prospective study of the alfa group. Leukemia 2007;21(1):66-71.

27. van der Heiden PL, Jedema I, Willemze R, Barge RM. Efficacy and toxicity of gemtuzumab ozogamicin in patients with acute myeloid leukemia. Eur J Haematol 2006;76(5):409-13.

28. Leopold LH, Berger MS, Cheng SC, Cortes-Franco JE, Giles FJ, Estey EH. Comparative efficacy and safety of gemtuzumab ozogamicin monotherapy and high-dose cytarabine combination therapy in patients with acute myeloid leukemia in first relapse. Clin Adv Hematol Oncol 2003;1(4):220-5.

29. Alvarado Y, Tsimberidou A, Kantarjian H, Cortes J, Garcia-Manero G, Faderl S, Thomas D, Estey E, Giles FJ. Pilot study of Mylotarg, idarubicin and cytarabine combination regimen in patients with primary resistant or relapsed acute myeloid leukemia. Cancer Chemother Pharmacol. 2003;51(1):87-90.

30. Cortes J, Tsimberidou AM, Alvarez R, Thomas D, Beran M, Kantarjian H, Estey E, Giles FJ. Mylotarg combined with topotecan and cytarabine in patients with 
refractory acute myelogenous leukemia. Cancer Chemother Pharmacol. 2002;50(6):497-500.

31. Piccaluga PP, Martinelli G, Rondoni M, Malagola M, Gaitani S, Visani G, Baccarani M. First experience with gemtuzumab ozogamicin plus cytarabine as continuous infusion for elderly acute myeloid leukaemia patients. Leuk Res 2004;28(9):987-90.

32. Tsimberidou A, Cortes J, Thomas D, Garcia-Manero G, Verstovsek S, Faderl S, Albitar M, Kantarjian H, Estey E, Giles FJ. Gemtuzumab ozogamicin, fludarabine, cytarabine and cyclosporine combination regimen in patients with $\mathrm{CD} 33+$ primary resistant or relapsed acute myeloid leukemia. Leuk Res 2003;27(10):893-7.

33. Chevallier P, Delaunay J, Turlure P, Pigneux A, Hunault M, Garand R, Guillaume T, Avet-Loiseau H, Dmytruk N, Girault S and others. Long-term disease-free survival after gemtuzumab, intermediate-dose cytarabine, and mitoxantrone in patients with CD33(+) primary resistant or relapsed acute myeloid leukemia. J Clin Oncol 2008;26(32):5192-7.

34. Chevallier P, Roland V, Mahé B, Juge-Morineau N, Dubruille V, Guillaume T, Vigouroux S, Moreau P, Milpied N, Garand R and others. Administration of mylotarg 4 days after beginning of a chemotherapy including intermediate-dose aracytin and mitoxantrone (MIDAM regimen) produces a high rate of complete hematologic remission in patients with $\mathrm{CD} 33+$ primary resistant or relapsed acute myeloid leukemia. Leuk Res 2005;29(9):1003-7.

35. Moore J, Seiter K, Kolitz J, Stock W, Giles F, Kalaycio M, Zenk D, Marcucci G. A Phase II study of Bcl-2 antisense (oblimersen sodium) combined with gemtuzumab ozogamicin in older patients with acute myeloid leukemia in first relapse. Leuk Res 2006;30(7):777-83. 
36. Nand S, Godwin J, Smith S, Barton K, Michaelis L, Alkan S, Veerappan R, Rychlik K, Germano E, Stiff P. Hydroxyurea, azacitidine and gemtuzumab ozogamicin therapy in patients with previously untreated non-M3 acute myeloid leukemia and high-risk myelodysplastic syndromes in the elderly: results from a pilot trial. Leuk Lymphoma 2008;49(11):2141-7.

37. Kell WJ, Burnett AK, Chopra R, Yin JA, Clark RE, Rohatiner A, Culligan D, Hunter A, Prentice AG, Milligan DW. A feasibility study of simultaneous administration of gemtuzumab ozogamicin with intensive chemotherapy in induction and consolidation in younger patients with acute myeloid leukemia. Blood 2003;102(33):4277-83.

38. Morris KL, Adams JA, Liu JA. Effect of gemtuzumab ozogamicin on acute myeloid leukemia blast cells in vitro, as a single agent and combined with other cytotoxic cells. Br J Haematol 2006;135(4):509-12.

39. Linenberger ML. CD33-directed therapy with gemtuzumab ozogamicin in acute myeloid leukemia: progress in understanding cytotoxicity and potential mechanisms of drug resistance. Leukemia 2005;19(2):176-82.

40. Zein N, Sinha AM, McGahren WJ, Ellestad GA. Calicheamicin gamma 1I: an antitumor antibiotic that cleaves double-stranded DNA site specifically. Science 1988;240(4856):1198-201.

41. van der Velden VH, Boeckx N, Jedema I, te Marvelde JG, Hoogeveen PG, Boogaerts M, van Dongen JJ. High CD33-antigen loads in peripheral blood limit the efficacy of gemtuzumab ozogamicin (Mylotarg) treatment in acute myeloid leukemia patients. Leukemia 2004;18(5):983-8.

42. Wadleigh M, Richardson PG, Zahrieh D, Lee SJ, Cutler C, Ho V, Alyea EP, Antin JH, Stone RM, Soiffer RJ and others. Prior gemtuzumab ozogamicin exposure 
significantly increases the risk of veno-occlusive disease in patients who undergo myeloablative allogeneic stem cell transplantation. Blood 2003;102(5):1578-82.

43. Estey EH, Thall PF, Giles FJ, Wang XM, Cortes JE, Beran M, Pierce SA, Thomas DA, Kantarjian HM. Gemtuzumab ozogamicin with or without interleukin 11 in patients 65 years of age or older with untreated acute myeloid leukemia and highrisk myelodysplastic syndrome: comparison with idarubicin plus continuousinfusion, high-dose cytosine arabinoside. Blood 2002;99(12):4343-9. 


\section{Figure legends}

Figure 1: Estimated overall survival according to treatment schedule. OS was 2.2 months ("GO $\rightarrow$ chx"), 7.2 months ("GO") and 14.8 months (chx $\rightarrow \mathrm{GO}$ ), respectively $(\mathrm{p}<0.001, \log$ rank test)

Figure 2: Survival of all patients receiving a GO containing therapy (OS 10.9 months) compared to a matched control group treated without GO (OS 3.4 months, $\mathrm{p}=0.11$, $\log$ rank test)

Figure 3: Representative MSP analysis of SOCS3 in AML patient samples. Normal peripheral blood (PB) and. in vitro methylated DNA (IVD) and water served as controls. Lane $\boldsymbol{U}$, amplified product with primers recognizing unmethylated SOCS3 sequence. Lane $M$, amplified product recognizing methylated SOCS3 sequence.

Figure 4: Survival according to the methylation status of SOCS3 (25.1 months vs. 10.3 months, $\mathrm{p}=0.09, \log$ rank test) 
Table I: Patient characteristics and response; $\mathrm{CR}=$ complete remission, $\mathrm{PR}=$ partial remission, $\mathrm{TF}=$ treatment failure, $\mathrm{OR}=$ overall response

\begin{tabular}{|c|c|c|c|c|c|c|}
\hline & all patients & GO & $\mathrm{GO} \rightarrow \operatorname{chx}$ & $\operatorname{chx} \rightarrow \mathrm{GO}$ & $\begin{array}{r}\text { p-value } \\
\text { (among Pts } \\
\text { with GO) }\end{array}$ & $\begin{array}{l}\text { matched } \\
\text { controls }\end{array}$ \\
\hline no. of patients & 24 & 3 & 5 & 16 & & 24 \\
\hline $\begin{array}{l}\text { age (years) } \\
\text { mean (range) }\end{array}$ & $66(43-82)$ & $76(70-82)$ & $62(43-74)$ & $65(43-76)$ & n.s. & $61(38-84)$ \\
\hline $\begin{array}{l}\text { disease status } \\
\text { refractory } \\
\text { 1. relapse } \\
\geq 2 \text {. relapse }\end{array}$ & $\begin{array}{r}12 \\
8 \\
4\end{array}$ & $\begin{array}{l}2 \\
1 \\
0\end{array}$ & $\begin{array}{l}1 \\
2 \\
2\end{array}$ & $\begin{array}{l}9 \\
5 \\
2\end{array}$ & n.s. & $\begin{array}{r}12 \\
11 \\
1\end{array}$ \\
\hline $\begin{array}{l}\text { risk group } \\
\text { favorable } \\
\text { intermediate } \\
\text { poor } \\
\text { not available } \\
\end{array}$ & $\begin{array}{r}0 \\
19 \\
2 \\
3 \\
\end{array}$ & $\begin{array}{l}0 \\
3 \\
0 \\
0\end{array}$ & $\begin{array}{l}0 \\
4 \\
0 \\
1\end{array}$ & $\begin{array}{r}0 \\
12 \\
2 \\
2 \\
\end{array}$ & n.s. & $\begin{array}{r}0 \\
20 \\
2 \\
2 \\
\end{array}$ \\
\hline $\begin{array}{l}\text { response } \\
\text { CR/CRp } \\
\mathrm{PR} \\
\text { TF } \\
\text { OR }(\mathrm{CR}(\mathrm{p}) / \mathrm{PR}) \\
\text { not available } \\
\text { early deaths }\end{array}$ & $\begin{array}{r}13 \\
1 \\
9 \\
14(61 \%) \\
1 \\
4(17 \%) \\
\end{array}$ & $\begin{array}{r}0 \\
1 \\
2 \\
1(33 \%) \\
0 \\
0(0 \%) \\
\end{array}$ & $\begin{array}{r}0 \\
0 \\
5 \\
0(0 \%) \\
0 \\
2(40 \%) \\
\end{array}$ & $\begin{array}{r}13 \\
0 \\
2 \\
13(81 \%) \\
1 \\
2(13 \%) \\
\end{array}$ & 0.01 & $\begin{array}{r}8 \\
1 \\
14 \\
9(38 \%) \\
1 \\
4(17 \%) \\
\end{array}$ \\
\hline
\end{tabular}


Table II: Treatment schedules; $\mathrm{GO}=$ gemtuzumab ozogamicin, araC $=$ cytosine arabinoside, $\mathrm{PO}=$ orally, $\mathrm{SC}=$ subcutaneously

\begin{tabular}{|c|c|}
\hline $\begin{array}{l}\text { patient } \\
\text { number }\end{array}$ & protocol \\
\hline \multicolumn{2}{|l|}{ GO } \\
\hline 2 & GO $9 \mathrm{mg} / \mathrm{m}^{2}$ day 1 \\
\hline 1 & GO $9 \mathrm{mg} / \mathrm{m}^{2}$ day 1 and day 20 \\
\hline \multicolumn{2}{|c|}{ GO $\rightarrow$ Chemo } \\
\hline 1 & $\begin{array}{l}\text { GO } 9 \mathrm{mg} / \mathrm{m}^{2} \mathrm{~d} 1 \text {, idarubicin } 12 \mathrm{mg} / \mathrm{m}^{2} \text { qd day } 11-12 \text {, araC } 100 \mathrm{mg} / \mathrm{m}^{2} \mathrm{qd} \text { day } \\
11-15\end{array}$ \\
\hline 3 & $\begin{array}{l}\text { GO } 9 \mathrm{mg} / \mathrm{m}^{2} \mathrm{~d} 1 \text {, mitoxantrone } 10 \mathrm{mg} / \mathrm{m}^{2} \text { qd day } 2-4 \text {, etoposide } 100 \mathrm{mg} / \mathrm{m}^{2} \mathrm{qd} \\
\text { day } 2-4\end{array}$ \\
\hline 1 & $\begin{array}{l}\text { GO } 9 \mathrm{mg} / \mathrm{m}^{2} \mathrm{~d} 1 \text {, idarubicin } 12 \mathrm{mg} / \mathrm{m}^{2} \mathrm{qd} \text { day } 2-4 \text {, topotecan } 1.25 \mathrm{mg} / \mathrm{m}^{2} \mathrm{qd} \\
\text { day } 2-4, \text { araC } 1000 \mathrm{mg} / \mathrm{m}^{2} \mathrm{qd} \text { day } 2-6\end{array}$ \\
\hline \multicolumn{2}{|c|}{ Chemo $\rightarrow$ GO } \\
\hline 5 & $\begin{array}{l}\text { araC } 3 \mathrm{mg} / \mathrm{kg} \text { sc q12h day } 1-7, \text { thioguanine } 2.5 \mathrm{mg} / \mathrm{kg} \text { PO qd, day } 1-7, \text { GO } 9 \\
\mathrm{mg} / \mathrm{m}^{2} \text { once (between day } 7 \text { and } 17 \text { ) }\end{array}$ \\
\hline 9 & $\begin{array}{l}\text { mitoxantrone } 10 \mathrm{mg} / \mathrm{m}^{2} \mathrm{qd} \text { day } 1-3 \text {, etoposide } 100 \mathrm{mg} / \mathrm{m}^{2} \mathrm{qd} \text { day } 1-3, \text { GO } 9 \\
\mathrm{mg} / \mathrm{m}^{2} \text { once (between day } 5 \text { and } 16 \text { ) }\end{array}$ \\
\hline 1 & $\begin{array}{l}\text { fludarabin } 30 \mathrm{mg} / \mathrm{m}^{2} \text { qd day } 1-5 \text {; araC } 2000 \mathrm{mg} / \mathrm{m}^{2} \text { qd day } 1-5 \text {; idarubicin } 10 \\
\mathrm{mg} / \mathrm{m}^{2} \mathrm{qd} \text { day } 1-3 \text {, GO } 9 \mathrm{mg} / \mathrm{m}^{2} \text { day } 14\end{array}$ \\
\hline 1 & $\begin{array}{l}\text { idarubicin } 12 \mathrm{mg} / \mathrm{m}^{2} \text { qd day } 1-2 \text {, araC } 100 \mathrm{mg} / \mathrm{m}^{2} \text { qd day } 1-5, \text { GO } 9 \mathrm{mg} / \mathrm{m}^{2} \text { day } \\
15\end{array}$ \\
\hline
\end{tabular}




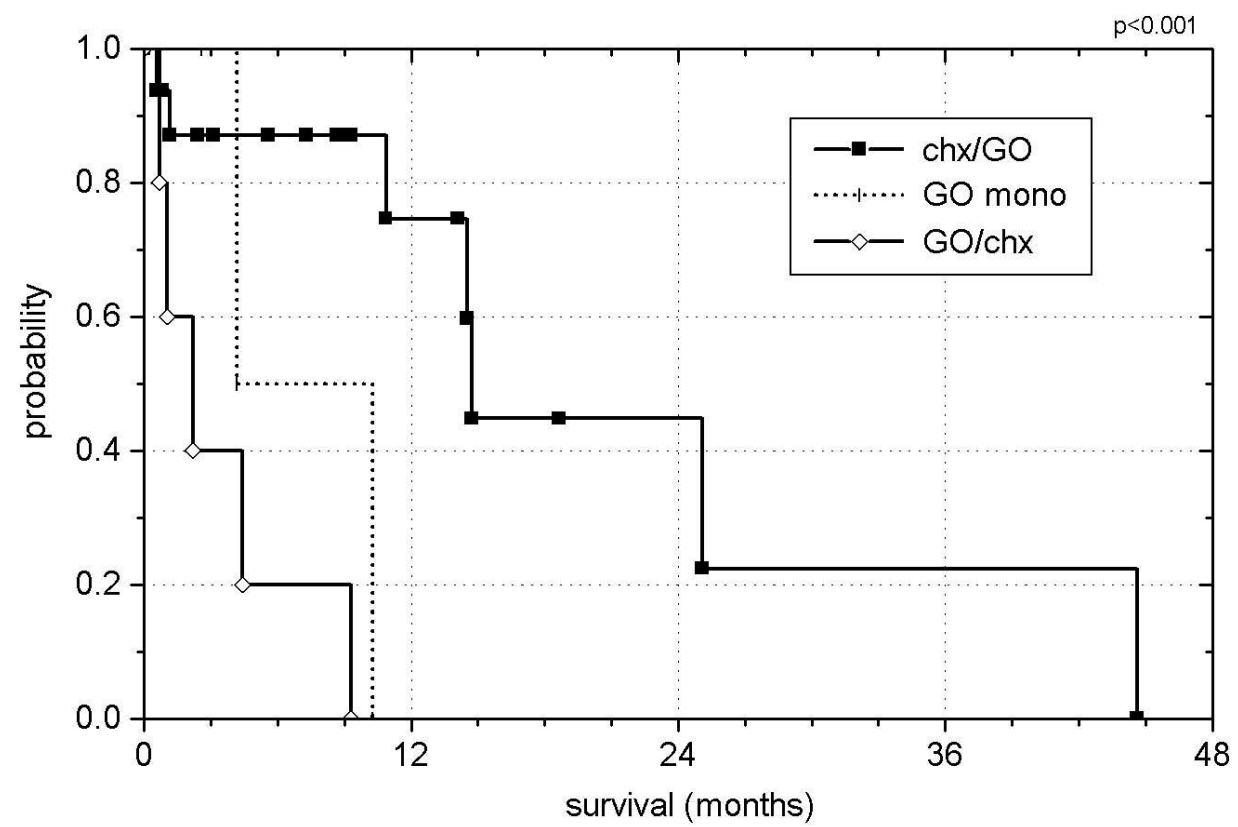

Estimated overall survival according to treatment schedule. OS was 2.2 months ("GO $\rightarrow$ chx"), 7.2 months ("GO") and 14.8 months (chx $\rightarrow \mathrm{GO})$, respectively ( $\mathrm{p}<0.001$, log rank test) $296 \times 201 \mathrm{~mm}(120 \times 120 \mathrm{DPI})$ 


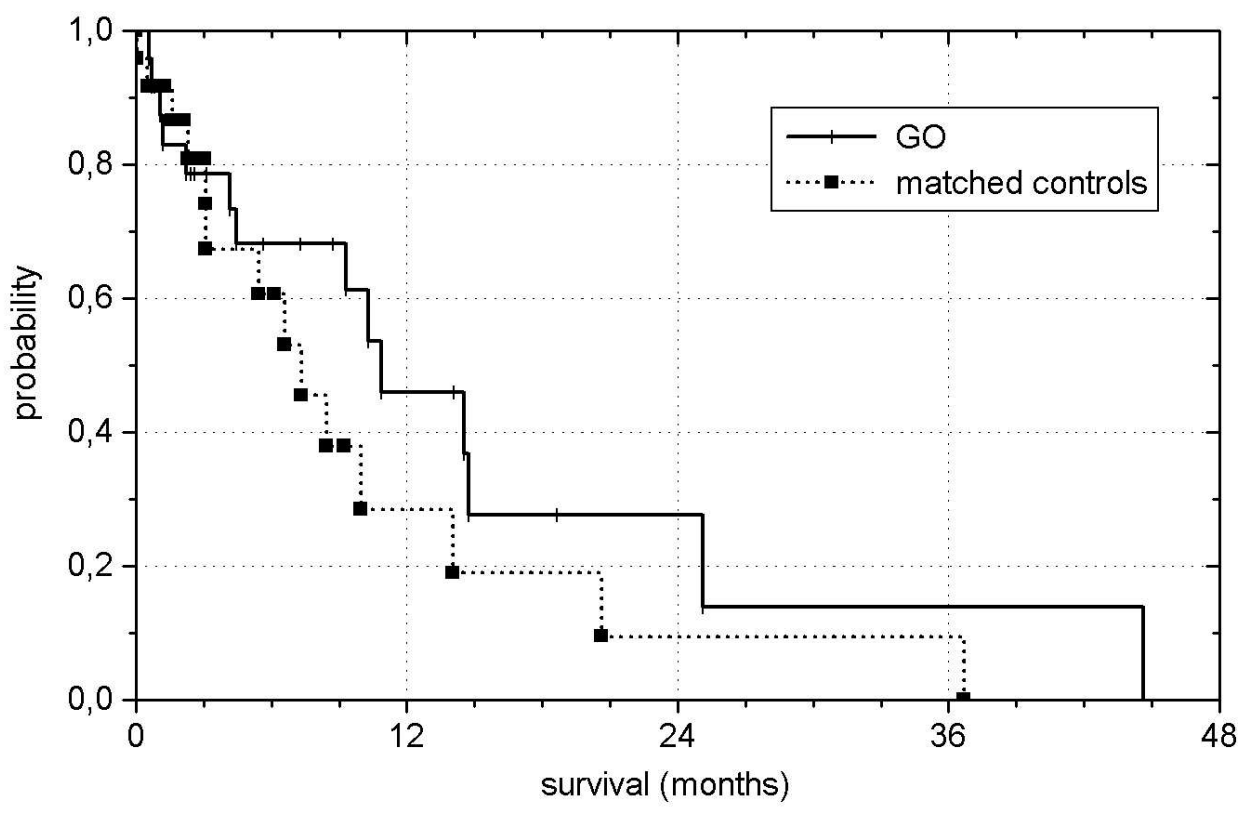

Survival of all patients receiving a GO containing therapy (OS 10.9 months) compared to a matched control group treated without GO (OS 3.4 months, $p=0.11$, log rank test) $296 \times 201 \mathrm{~mm}(120 \times 120 \mathrm{DPI})$ 
Representative MSP analysis of SOCS3 in AML patient samples. Normal peripheral blood (PB) and. in vitro methylated DNA (IVD) and water served as controls. Lane $U$, amplified product with primers recognizing unmethylated SOCS3 sequence. Lane $\mathrm{M}$, amplified product recognizing methylated SOCS3 sequence. $690 \times 88 \mathrm{~mm}(96 \times 96$ DPI $)$ 


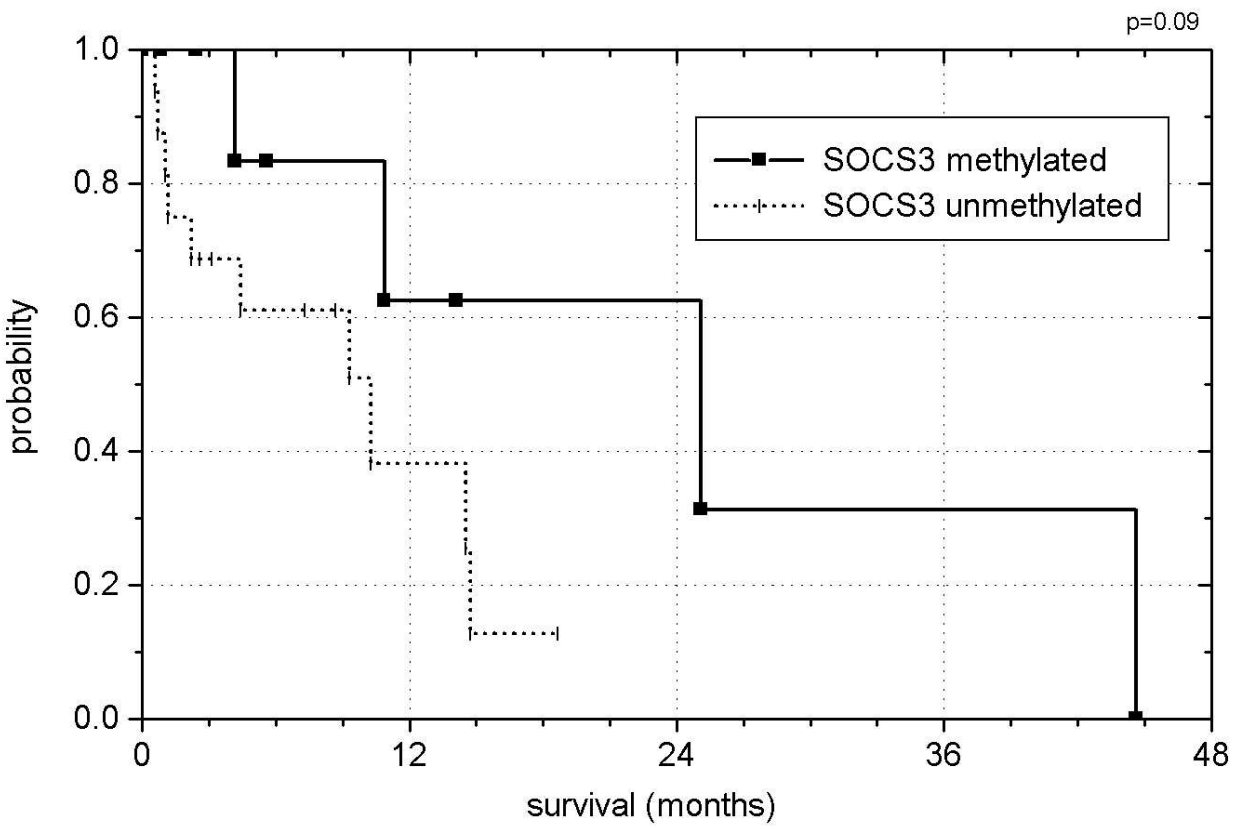

Survival according to the methylation status of SOCS3 ( 25.1 months vs. 10.3 months, $p=0.09$, log rank test)

$296 \times 201 \mathrm{~mm}(120 \times 120 \mathrm{DPI})$ 